$1-1-1982$

\title{
Selenium status of beef cattle and sheep in West Virginia and Pennsylvania
}

Donna Lynn Stadtmore

R. L. Reid
G. A. Jung

Follow this and additional works at: https://researchrepository.wvu.edu/ wv_agricultural_and_forestry_experiment_station_bulletins

\section{Digital Commons Citation}

Stadtmore, Donna Lynn; Reid, R. L.; and Jung, G. A., "Selenium status of beef cattle and sheep in West Virginia and Pennsylvania" (1982). West Virginia Agricultural and Forestry Experiment Station Bulletins. 679T.

https://researchrepository.wvu.edu/wv_agricultural_and_forestry_experiment_station_bulletins/727 


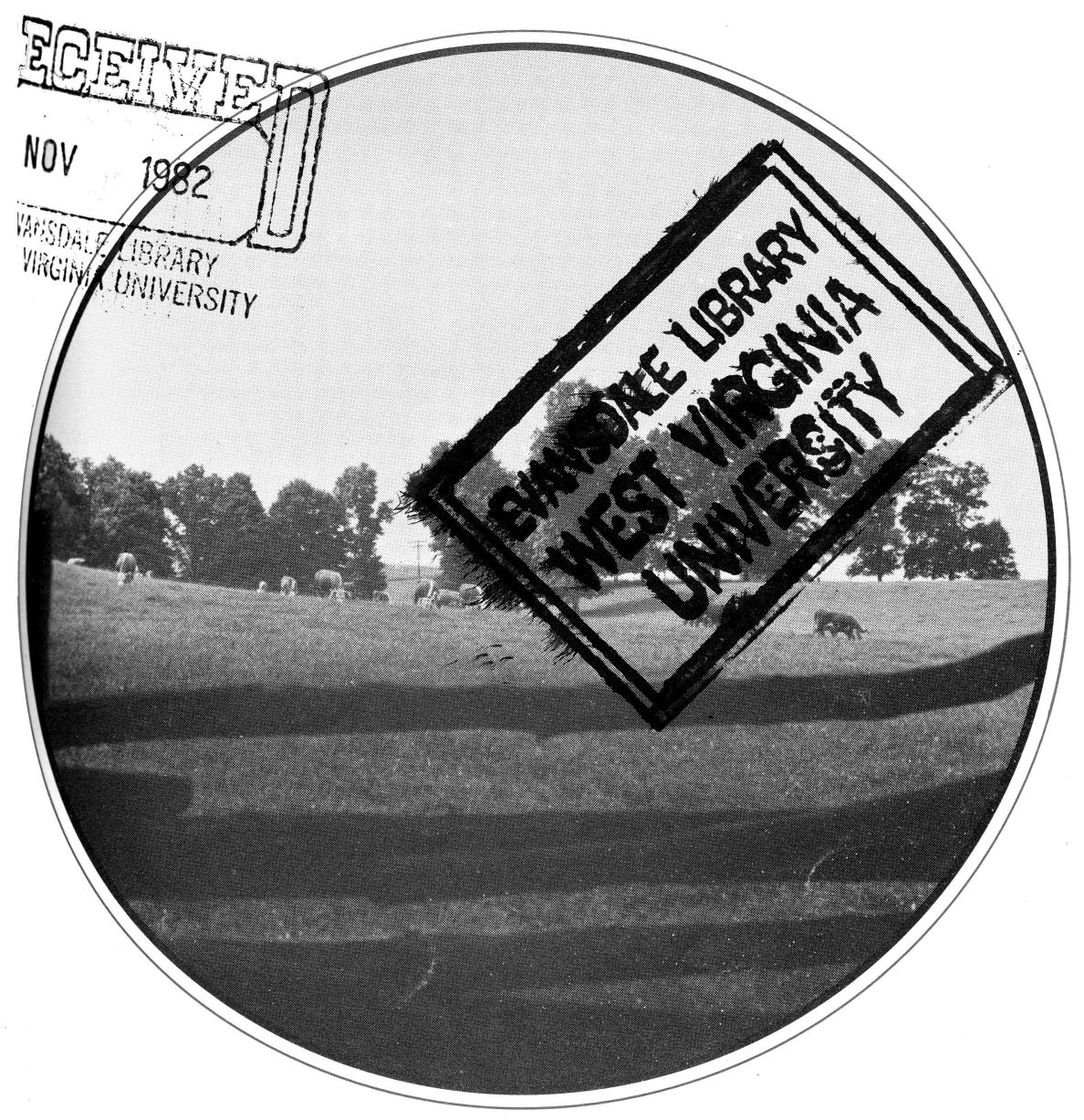

Bulletin 679T

September 1982

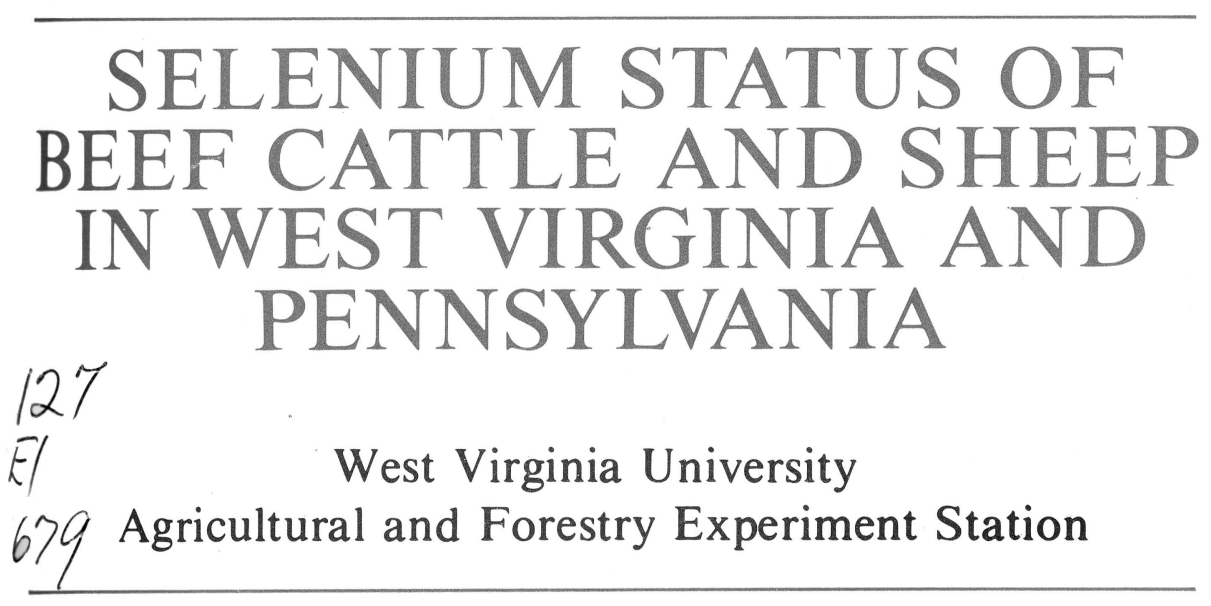




\section{AUTHORS}

D. L. Stadtmore was research assistant in Animal Nutrition and R. L. Reid is animal nutritionist, West Virginia Agricultural and Forestry Experiment Station. G. A. Jung is with the U.S. Regional Pasture Research Laboratory, University Park, Pa.

\section{ACKNOWLEDGMENT}

The authors acknowledge the assistance of Dr. Frank Woodson, Mr. Robert Wagner, and Ms. Linda Vona in the collection of blood and pasture samples, and thank Dr. W. V. Thayne for his help with statistical analysis of data.

WEST VIRGINIA UNIVERSITY

AGRICULTURAL AND FORESTRY EXPERIMENT STATION COLLEGE OF AGRICULTURE AND FORESTRY

DALE W. ZINN, DIRECTOR MORGANTOWN 


\section{Contents}

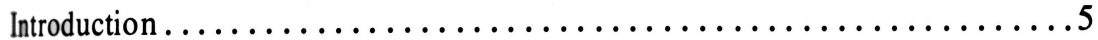

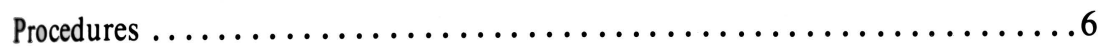

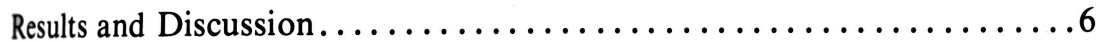

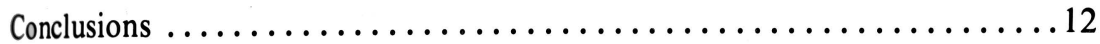

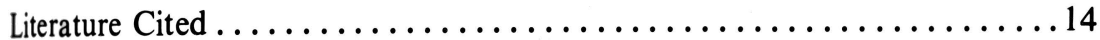


Blank Page in Original Bulletin 


\title{
Selenium Status of Beef Cattle and Sheep in West Virginia and Pennsylvania
}

\author{
D. L. Stadtmore, R. L. Reid, and G. A. Jung
}

\section{Introduction}

Selenium (Se)-responsive diseases of livestock occur frequently in the United States and have been responsible for serious economic losses. Animals consuming a diet low or deficient in selenium $(<.05 \mathrm{ppm})$ are susceptible to many problems, including white muscle disease in lambs and calves, calf pneumonia, infertility, increased incidence of retained placentae by cows (Julien et al., 1976; Trinder et al., 1969, 1973), and increased uterine and udder infections. More insidious is the condition of "unthriftiness" and poor growth, which is reported as the most widespread selenium-responsive disease in sheep and cattle in New Zealand (Watkinson and Grant, 1981). This occurs typically on improved pastures in good growing seasons when the herbage contains less than $.03 \mathrm{ppm}$ Se and results in depressed growth rates, reduced milk production in lactating cows, and lower wool production in sheep.

The most selenium-deficient regions in the United States are found in the Northwest, Southeast, and the Northeast, including many of the states adjoining the Great Lakes. A map describing the regional distribution of selenium concentrations in forage crops indicated that low levels of selenium ( 80 percent of all samples containing less than $.10 \mathrm{ppm} \mathrm{Se}$ ) were found in areas of Ohio, Indiana, Illinois, Michigan, and Wisconsin, and all of West Virginia, Pennsylvania, Maryland, New York, and New England (Kubota et al., 1967). Soils in these states are derived mainly from old sedimentary rocks and are frequently acidic in nature; in consequence, the selenium that is present may be relatively unavailable to plants.

Metabolic problems associated with a dietary deficiency of selenium have been reported on a sporadic basis from various states in the northeastern region and it has been recommended that ruminant animals receive supplementary selenium in the ration. While West Virginia has been described as a selenium-deficient area, there is little experimental evidence to indicate 
whether soils and pastures are, in fact, lacking in selenium, or whether farm livestock would respond to the addition of selenium in the diet. As an initial step in a series of trials to examine the selenium status of sheep maintained on pasture or hay diets (Stadtmore, 1981), a survey was conducted during the summer and early fall of 1978 to determine blood concentrations of selenium and glutathione peroxidase (a selenoenzyme) in lactating beef cows and sheep at different sites in northeastern West Virginia and southwestern Pennsylvania, and to relate these to concentrations of selenium in pasture herbage. The trials were run in cooperation with the Agricultural Research Service (USDA Pasture Research Labs., University Park) and with staff in the Allegheny Highlands Project and the Agricultural Extension Service in West Virginia. Counties and farms were selected on the basis of farmers' and extension agents' interest in the project and the availability of suitable handling facilities for animals.

\section{Procedures}

The survey included seven counties in West Virginia and eight counties in Pennsylvania (Figure 1). On each of 24 farms over a 16-week period, 15 lactating beef cows and/or ewes were bled by jugular venipuncture into heparinized Vacutainers. Blood was normally obtained between 0900 and 1200 hours. All whole blood samples were analyzed within 6 hours for glutathione peroxidase (GSH-Px) activity by the method of Board and Peter (1976). Blood samples were then immediately frozen until selenium analysis was conducted by the technique of Olson et al. (1975). Hemoglobin was determined on all blood samples using a Hemoglobinometer. Forage samples were collected at random from pastures the animals had been grazing for at least one month prior to bleeding. The samples were composited and air dried at room temperature to minimize losses of Se by volatilization. Dried samples were ground in a Wiley mill using a stainless steel $1-\mathrm{mm}$ screen. Selenium was determined fluorometrically by the method of Olson et al. (1975) on all ground samples. Sulfur concentration of forage samples was determined by a Leco induction furnace method and nitrogen by the Kjeldahl technique. Calcium, phosphorus, magnesium, potassium, iron, aluminum, manganese, copper, zinc, and sodium concentrations in forage samples were run by an emission spectrographic method at the Pennsylvania Forage Testing Laboratory, University Park.

Analysis of variance and regression analysis on experimental data were run by standard methods (Steel and Torrie, 1960).

\section{Results and Discussion}

Whole blood selenium concentrations for lactating beef cows and ewes were found to be generally within normal ranges of $.05 \mathrm{ppm}$ to $.15 \mathrm{ppm} \mathrm{Se}$ (NRC, 


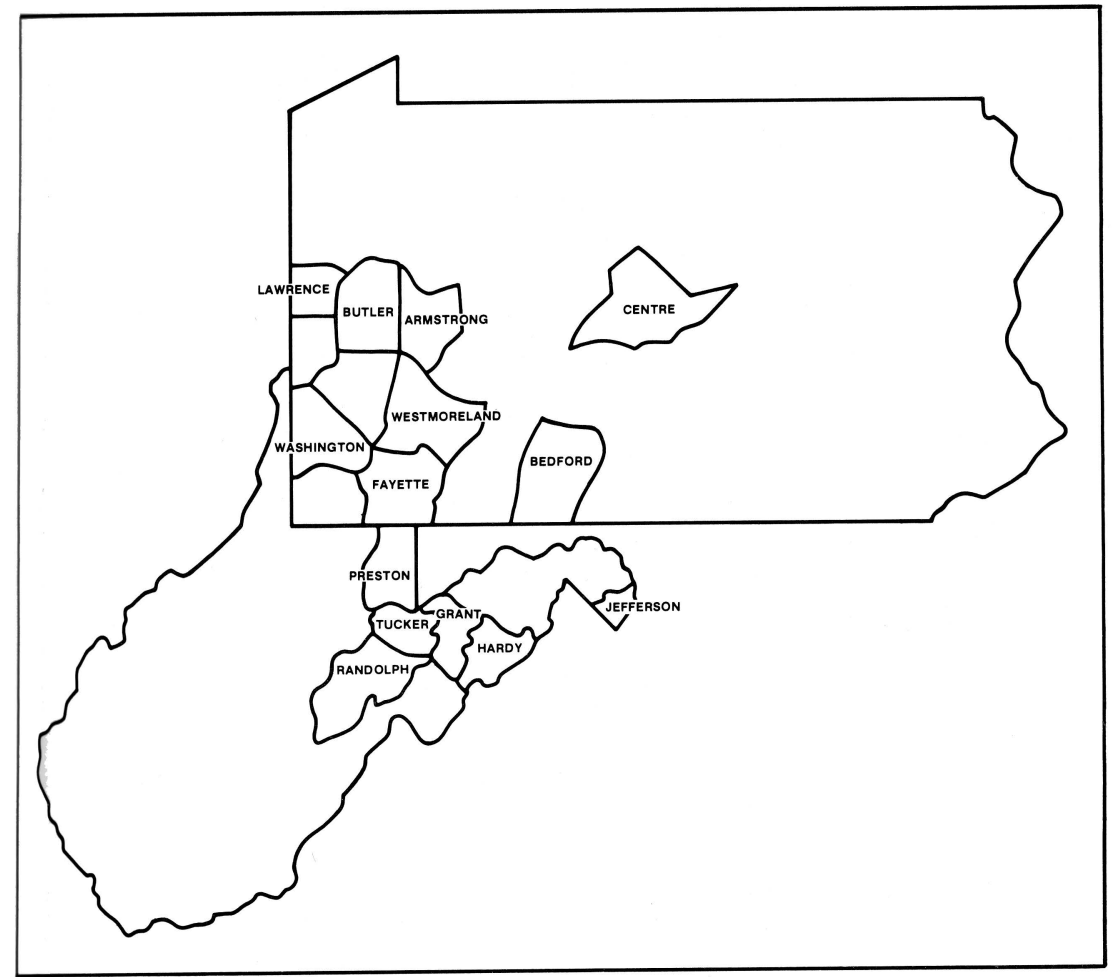

Figure 1. Location of beef herds and sheep flocks surveyed in West Virginia and Pennsylvania.

1975, 1976) for these species (Table 1). For all beef cows (251), selenium concentrations and GSH-Px activities ranged from .06 to $.29 \mathrm{ppm}$, and from 52 to $257 \mathrm{EU} / \mathrm{gHb}$, respectively, with mean values of .12 ppm Se and 121 $\mathrm{EU} / \mathrm{gHb} \mathrm{GSH}-\mathrm{Px}$ activity. These values were found to be consistently lower $(\mathrm{P}<.01)$ than for the ewes. For all ewes (225), selenium concentrations and GSH-Px activities ranged from .07 to $.30 \mathrm{ppm}$, and from 52 to $310 \mathrm{EU} / \mathrm{gHb}$, respectively, with mean values of $.16 \mathrm{ppm} \mathrm{Se}$ and $183 \mathrm{EU} / \mathrm{gHb}$ GSH-Px activity. In Pennsylvania, mean blood Se concentrations ranged from $.07 \mathrm{ppm}$ in Bedford County to $.24 \mathrm{ppm}$ in Lawrence and Butler counties. There was also appreciable diversity in blood selenium concentrations in West Virginia. Values ranged from $.08 \mathrm{ppm}$ in Hardy County to $.16 \mathrm{ppm}$ in Grant County. This range in selenium values between geographic areas may be associated 
Table 1.

Selenium concentrations and glutathione peroxidase activities in blood of grazing beef cows and ewes.

\begin{tabular}{lcccc}
\hline \hline $\begin{array}{l}\text { State and } \\
\text { County }\end{array}$ & \multicolumn{2}{c}{$\begin{array}{c}\text { Selenium } \\
\text { ppm }\end{array}$} & \multicolumn{2}{c}{$\begin{array}{c}\text { Glutathione Peroxidase } \\
\text { EU/g Hb }\end{array}$} \\
\hline $\begin{array}{l}\text { Pennsylvania } \\
\text { Westmoreland }\end{array}$ & cows & sheep & cows & sheep \\
Armstrong & $.19 \pm .006$ & $.22 \pm .005$ & $136 \pm 10$ & $240 \pm 15$ \\
Lawrence & $.24 \pm .010$ & $.21 \pm .008$ & $97 \pm 5$ & $180 \pm 16$ \\
Butler & - & - & $137 \pm 11$ & - \\
Washington & $.13 \pm .010$ & $.24 \pm .013$ & - & $206 \pm 12$ \\
Fayette & $.15 \pm .010$ & $.19 \pm .005$ & $117 \pm 5$ & $202 \pm 12$ \\
Centre & $.11 \pm .005$ & $.13 \pm .003$ & $172 \pm 9$ & $213 \pm 8$ \\
Bedford & $.07 \pm .002$ & $.19 \pm .010$ & $136 \pm 7$ & $183 \pm 23$ \\
West Virginia & & & & $187 \pm 8$ \\
Tucker & $.09 \pm .004$ & $.15 \pm .006$ & $94 \pm 7$ & $170 \pm 13$ \\
Grant & $.15 \pm .006$ & $.16 \pm .009$ & $138 \pm 7$ & $177 \pm 4$ \\
Preston & $.11 \pm .003$ & $.13 \pm .004$ & $126 \pm 7$ & $130 \pm 11$ \\
Randolph & $.11 \pm .005$ & $.13 \pm .002$ & $95 \pm 6$ & $140 \pm 9$ \\
Hardy & $.08 \pm .003$ & $.11 \pm .006$ & $132 \pm 7$ & $223 \pm 13$ \\
Jefferson & $.10 \pm .002$ & $.12 \pm .004$ & $101 \pm 8$ & $184 \pm 13$ \\
Mean & $.12(.06-.29)^{\mathrm{b}}$ & $.16(.07-.30)^{\mathrm{c}}$ & $121(52-257)^{\mathrm{b}}$ & $183(52-310)^{\mathrm{c}}$ \\
\hline
\end{tabular}

${ }^{a}$ Values represent means $( \pm \mathrm{SE})$ for 15 cows or sheep per herd or flock.

${ }^{b}$ Numbers in parentheses represent ranges for 251 cows.

${ }^{\mathrm{c}}$ Numbers in parentheses represent ranges for 225 sheep.

with differences in soil type and composition between counties, although Arthur et al. (1979) found little effect of soil parent material on blood Se concentrations and GSH-Px activities of cattle in Scotland. Blood selenium concentrations in herds and flocks in West Virginia were generally lower than in Pennsylvania, although there is no consistent pattern of soil differences between the two regions.

For cows, blood selenium and GSH-Px values tended $(\mathrm{P}<.06)$ to differ between counties, with less variation for selenium between herds within a county. Glutathione peroxidase activites, however, differed $(\mathrm{P}<.01)$ between herds within a county. For sheep, blood selenium concentrations and GSH-Px activities differed $(\mathrm{P}<.01)$ between counties; selenium levels also differed $(\mathrm{P}<.01)$ between flocks within a county, but differences between GSH-Px activities were not significant. 
A quadratic relationship $(\mathrm{P}<.05)$ was shown to exist between blood GSH-Px activities and whole blood Se concentrations in cows. However, there was no significant quadratic relationship in sheep (Figure 2).

The individual regressions were:

$$
\begin{aligned}
& Y_{b}=K+911 X-2269 X^{2}, s_{y . x} 27.9 \\
& Y_{0}=K+379 X-546 X^{2}, s_{y . x} 49.9
\end{aligned}
$$

where $\mathrm{K}=\mathrm{a}$ constant dependent on herd and county, $\mathrm{Y}=\mathrm{GSH}-\mathrm{Px}$ activity, $X=$ Se concentration, and the subscripts $b$ and o refer to bovine and ovine, respectively.

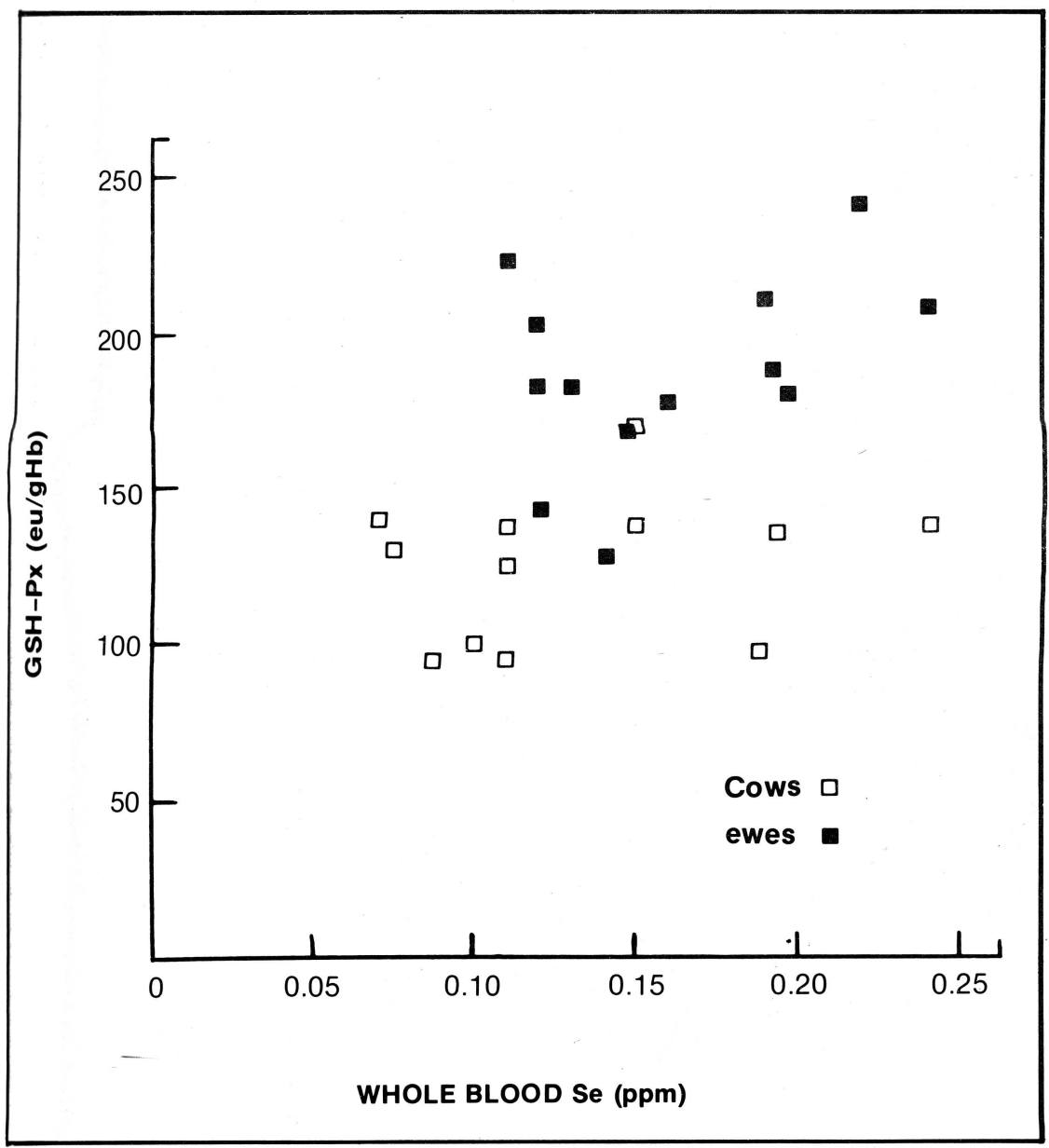

Figure 2. Relationship between whole blood selenium concentrations and glutathione peroxidase activities in cattle and sheep. 
For cows, 52 percent of the variation in activity of the enzyme was not accounted for by the level of blood selenium. For sheep, 70 percent of the variation was not accounted for by blood selenium concentrations. Variability in both regressions was sufficiently high to limit the use of the GSH-Px assay for predictive purposes.

A direct relationship between blood selenium concentrations and blood GSH-Px activities has been demonstrated for both cows and sheep in a number of other studies (Thompson et al., 1976; Anderson et al., 1979; Allen et al., 1975; Arthur et al., 1979; Wilson and Judson, 1976). In the present trials, GSH-Px activity was determined by a semi-quantitative spot test. Results of recent studies (Backall and Scholz, 1979; Berrett and Hebert, 1979) indicate that this screening test for GSH-Px activity is primarily a qualitative method and is limited in that it detects only large deviations from the "normal" reference values. This spot chromatographic procedure appears to be most useful for detecting grossly deficient GSH-Px activities, but is not well suited to the determination of graded levels of enzyme activity. The procedure does, however, have the advantages of simplicity, of using only minute quantities of blood, and of not requiring the use of expensive and elaborate equipment.

Mineral analyses of pasture samples are summarized in Table 2. Nitrogen in pasture samples ranged from 1.15 percent in Westmoreland County, $\mathrm{Pa}$., to 3.00 percent in Centre County, Pa. Calcium, phosphorus, and potassium concentrations ranged from .31 to .93 percent, .20 to .39 percent and 1.23 to 3.10 percent, respectively. The levels of nitrogen, calcium, phosphorus, and potassium in all pasture samples were generally adequate to meet the NRC requirements of beef cows of average milking ability (NRC, 1976) and of ewes in late lactation (NRC, 1975). Magnesium concentrations in pasture herbage ranged from .11 percent in Westmoreland County, Pa., to .23 percent in Jefferson County, W. Va. Farms situated in Lawrence County, Pa., with mean pasture magnesium levels of .12 percent had encountered problems of magnesium deficiency in their beef cattle herds over the years. Pasture magnesium concentrations were also low in Westmoreland and Armstrong counties, Pa., and in Grant and Preston counties, W. Va. Magnesium concentrations in pastures in these counties do not meet the NRC (1976) minimum requirement of .18 percent for lactating beef cows. Sulfur levels in forage samples ranged from .18 to .35 percent. There was a correlation of +.19 between selenium and sulfur levels in herbages. This relationship, however, was not significant. Concentrations of iron and manganese were adequate to provide the NRC recommended allowances for lactating beef cows and sheep: on the other hand, average sodium levels in forages in all counties would supply only a fraction of the NRC allowances for lactating beef cows and sheep. With the exception of pasture samples from Westmoreland County, $\mathrm{Pa}$., mean zinc concentrations were found to meet or exceed the NRC 
Table 2.

Mineral composition of pasture herbage in Pennsylvania and West Virginia. ${ }^{a}$

\begin{tabular}{|c|c|c|c|c|c|c|c|c|c|c|c|c|c|}
\hline \multirow[t]{2}{*}{ Location } & $\mathrm{N}$ & $\mathrm{Ca}$ & $\mathrm{P}$ & $\mathrm{Mg}$ & $\mathrm{K}$ & $\mathrm{S}$ & $\mathrm{Fe}$ & $\mathrm{Al}$ & $\mathrm{Mn}$ & $\mathrm{Cu}$ & $\mathrm{Zn}$ & $\mathrm{Na}$ & $\mathrm{Se}$ \\
\hline & \multicolumn{6}{|c|}{ Percentage } & \multicolumn{7}{|c|}{ Parts per million } \\
\hline \multicolumn{14}{|l|}{ Pennsylvania } \\
\hline Westmoreland & 1.15 & .31 & .24 & .11 & 2.29 & .19 & 37 & 27 & 96 & 5 & 18 & 61 & .15 \\
\hline Armstrong & 1.97 & .51 & .28 & .12 & 3.10 & .24 & 213 & 248 & 108 & 7 & 27 & 139 & .19 \\
\hline Lawrence & 1.67 & .55 & .20 & .12 & 2.65 & .24 & 112 & 117 & 57 & 7 & 26 & 81 & .24 \\
\hline Butler & 2.76 & .51 & .35 & .16 & 2.27 & .30 & 155 & 185 & 77 & 9 & 36 & 119 & .16 \\
\hline Washington & 2.14 & .53 & .24 & .15 & 1.78 & .30 & 214 & 220 & 133 & 7 & 31 & 70 & .12 \\
\hline Fayette & 2.83 & .47 & .38 & .19 & 2.87 & .35 & 172 & 197 & 109 & 9 & 33 & 248 & .17 \\
\hline Centre & 3.00 & .46 & .37 & .17 & 2.35 & .23 & 382 & 450 & 93 & 11 & 33 & 88 & .12 \\
\hline Bedford & 1.64 & .54 & .28 & .18 & 1.98 & .23 & 71 & 50 & 169 & 6 & 26 & 73 & .12 \\
\hline \multicolumn{14}{|l|}{ West Virginia } \\
\hline Tucker & 2.35 & .62 & .34 & .19 & 2.26 & .31 & 202 & 197 & 211 & 10 & 41 & 181 & .13 \\
\hline Grant & 1.32 & .43 & .20 & .13 & 1.23 & .18 & 101 & 105 & 430 & 3 & 25 & 45 & .12 \\
\hline Preston & 1.97 & .55 & .27 & .14 & 1.74 & .22 & 335 & 394 & 214 & 10 & 33 & 58 & .12 \\
\hline Randolph & 2.47 & .93 & .39 & .21 & 2.63 & .28 & 204 & 214 & 120 & 14 & 28 & 101 & .10 \\
\hline Hardy & 2.10 & .53 & .32 & .17 & 1.87 & .26 & 351 & 342 & 126 & 7 & 32 & 89 & .09 \\
\hline Jefferson & 2.74 & .52 & .28 & .23 & 1.58 & .21 & 152 & 139 & 74 & 6 & 30 & 68 & .12 \\
\hline
\end{tabular}

${ }^{\mathrm{a}}$ Dry matter basis. 
minimum allowances for these species. Copper values ranged from 3 to 14 ppm among all counties. Only the low copper concentrations ( $3 \mathrm{ppm})$ in herbage from Grant County, W. Va., fell below the NRC requirements for that element.

Selenium concentrations in herbage ranged from .09 to $.24 \mathrm{ppm}$. These values may be compared with concentrations of .02 to $.03 \mathrm{ppm}$ at which selenium-responsive myopathies have been reported in Australia and New Zealand (Gardiner et al., 1962; Andrews et al., 1968), and concentrations of less than $.05 \mathrm{ppm}$ in forages in selenium-deficient areas of the United States and Canada (Kubota et al., 1967; Arthur, 1971). Farms in Centre County, Pa., with mean forage concentrations of $.12 \mathrm{ppm}$ Se reported losing calves from white muscle disease during the spring of 1978. Pastures on farms in Fayette County, $\mathrm{Pa}$., which were situated near a power plant were found to be exposed to fly ash. Fly ash, which is produced in coal-burning, power-generating plants (Gutenmann et al., 1976) has been found to contain high amounts of selenium (Furr et al., 1977). This may account for the relatively high selenium levels at this site. The higher herbage selenium concentrations in southwestern Pennsylvania as compared to West Virginia may, in fact, reflect their closer proximity to industrial sites, such as those involved in the production of iron and steel alloys or in the manufacture of glass and ceramics (NAS, 1976).

There was a correlation of $+.80(\mathrm{P}<.01)$ between selenium concentrations of pastures and mean whole blood selenium concentrations for all herds and flocks in the survey (Figure 3). Although Kubota et al. (1967) classified Pennsylvania and West Virginia forages as being deficient in selenium, with a median concentration of .05 ppm, it is evident that the majority of the values obtained in this study fell within a range of .10 to $.15 \mathrm{ppm} \mathrm{Se}$.

\section{Conclusions}

1. There was little indication, from this survey, that beef cattle and sheep grazing typical hill pastures in West Virginia and Pennsylvania during the summer months are deficient in selenium. Both pasture concentrations and blood levels of selenium in cows and ewes were within "normal" ranges, in which no responses to supplemental dietary selenium have been observed. The data do not support previous observations, based on a limited number of forage analyses, that West Virginia is a selenium-deficient area. This is not to say that selenium-deficiency conditions may not occur at other times of the year or in animals of different physiological status. Further studies with lactating dairy cows and with lambs during the early growth period are, for example, indicated.

2. Beef cows had consistently lower blood selenium concentrations and glutathione peroxidase activities than ewes. This may reflect either differences in selenium metabolism between the species or, possibly, differences in 


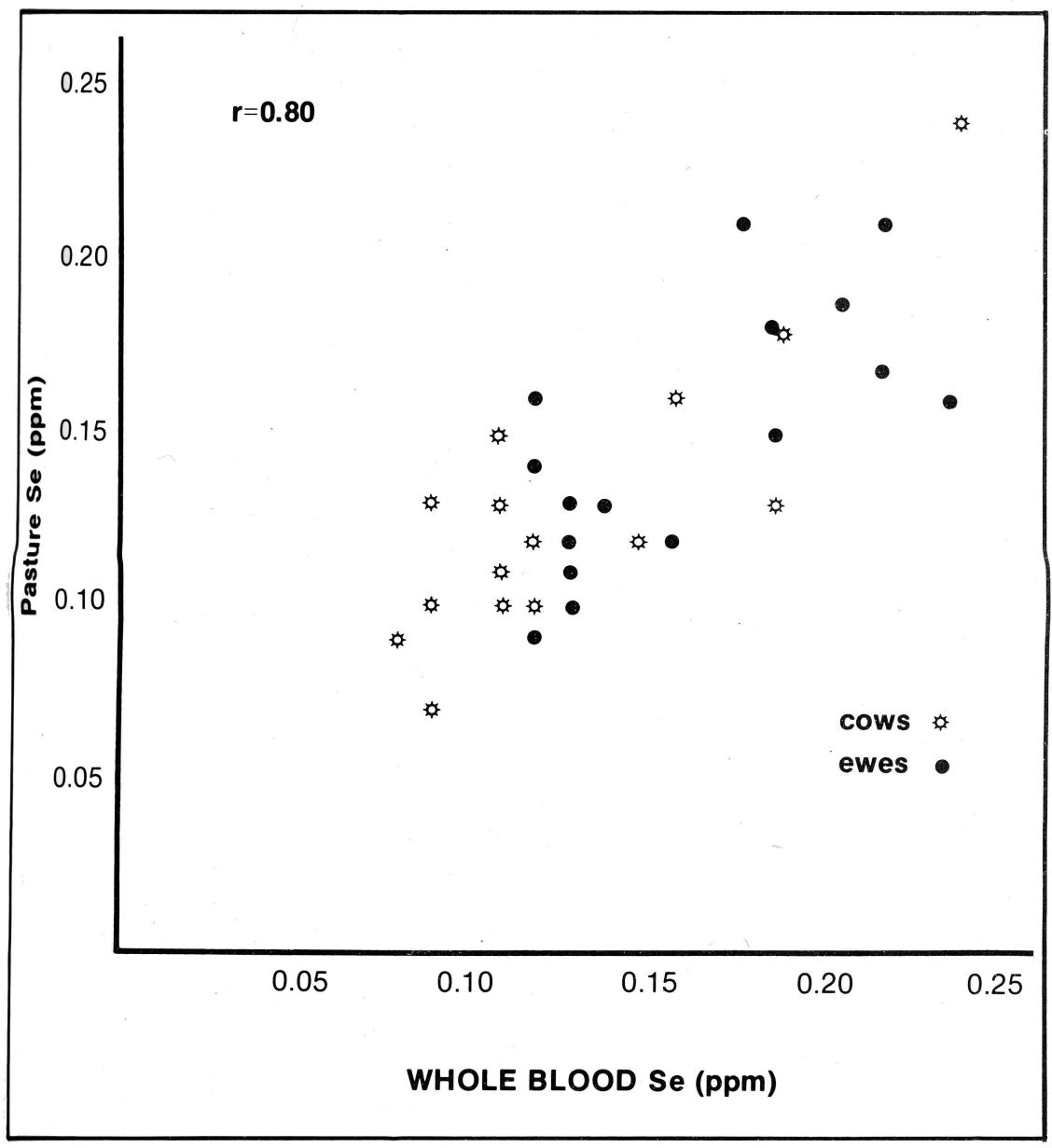

Figure 3. Relationship between selenium concentrations in pasture and blood selenium concentrations in cattle and sheep.

grazing behavior and herbage selection. The considerable variations within species in blood selenium concentrations appear to result mainly from differences in selenium content of the herbage, which may in turn relate to soil type, fertility status, balance of plant species in the pasture, and, possibly, environmental contamination.

3. While there was a positive relationship between blood selenium concentrations and glutathione peroxidase activities in animals sampled in this study, the relationship varied with species and was not sufficiently high to warrant the use of the enzyme assay for routine prediction of the selenium status of ruminant livestock. 


\section{Literature Cited}

Allen, W. M., W. H. Parr, P. H. Anderson, S. Berrett, R. Bradley and D. S. P. Patterson. 1975. "Selenium and the activity of glutathione peroxidase in bovine erythrocytes," Vet. Rec. 96:360.

Anderson, P. H., S. Berrett and D. S. P. Patterson. 1979. "The biological selenium status of livestock in Britain as indicated by sheep erythrocyte gluthathione peroxidase activity," Vet. Rec. 104:235.

Andrews, E. D., W. J. Hartley and A. B. Grant. 1968. "Selenium-responsive diseases of animals in New Zealand," N.Z. Vet. J. 16:3.

Arthur, D. 1971. "Selenium content of some food ingredients available in Canada," Can. J. Anim. Sci. 51:71.

Arthur, J. R., J. Price and C. F. Mills. 1979. "Observations on the selenium status of cattle in the northeast of Scotland," Vet. Rec. 104:340.

Backall, K. A. and R. W. Scholz. 1979. "Reference values for a field test to estimate inadequate glutathione peroxidase activity and selenium status in the blood of cattle," Am. J. Vet. Res. 40:733.

Berrett, S. and C. N. Hebert. 1979. "A semi-quantitative spot test for glutathione peroxidase in blood of cattle and sheep for the assessment of biological selenium status," Vet. Rec. 105:145.

Board, P. G. and D. W. Peter. 1976. "A simple test for glutathione peroxidase and selenium deficiency," Vet. Rec. 99:144.

Furr, A. K., T. F. Parkinson, R. A. Hinricks, D. R. Van Campen, C. A. Bache, W. H. Gutenmann, L. E. St. John, Jr., I. S. Pakkala, and D. J. Lisk. 1977. "National survey of elements and radioactivity in fly ashes," Environ. Sci. Technol. 11:1194.

Gardiner, M. R., J. Armstrong, H. Fels and R. N. Glencross. 1962. "A preliminary report on selenium and animal health in Western Australia," Aust. J. Exp. Agric. Anim. Husb. 2:261.

Gutenmann, W. H., C. A. Bache, W. D. Youngs and D. J. Lisk. 1976. "Selenium in fly ash," Science 191:966.

Julien, W. E., H. R. Conrad, J. E. Jones and A. L. Moxon. 1976. "Selenium and Vitamin $E$ and incidence of retained placenta in parturient dairy cows," $J$. Dairy Sci. 59:1954.

Kubota, J., W. H. Allaway, D. L. Carter, E. E. Cary and V. A. Lazar. 1967. "Selenium in crops in the United States in relation to selenium-responsive diseases of animals," Agr. Food Chem. 15:448.

National Academy of Sciences. 1976. Selenium. Washington, D.C. 
NRC. 1975. Nutrient Requirements of Domestic Animals, No. 5. Nutrient Requirements of Sheep. National Academy of Sciences-National Research Council, Washington, D.C.

NRC. 1976. Nutrient Requirements of Domestic Animals, No. 4. Nutrient Requirements of Beef Cattle. National Academy of Sciences-National Research Council, Washington, D.C.

Olson, O. E., I. S. Palmer and E. E. Cary. 1975. "Modification of the official fluorometric method for selenium in plants," J. Assoc. Official Anal. Chem. 58:117.

Stadtmore, D. L. 1981. Selenium nutrition of ruminants on forage diets. Ph.D. Dissertation, West Virginia University, Morgantown.

Steel, R. G. D. and J. H. Torrie. 1960. Principles and procedures of statistics. McGraw-Hill Book Co., Inc., New York.

Thompson, R. H., C. H. McMurray and W. J. Blanchflower. 1976. "The levels of selenium and glutathione peroxidase activity in blood of sheep, cows and pigs," Res. Vet. Sci. 20:229.

Trinder, N., R. J. Hall and C. P. Renton. 1973. "The relationship between the intake of selenium and Vitamin E and the incidence of retained placenta in dairy cows," Vet. Rec. 93:641.

Trinder, N., D. Woodhouse and C. P. Renton. 1969. "The effect of Vitamin E and selenium on the incidence of retained placenta in dairy cows," Vet. Rec. 85:550.

Watkinson, J. H. and A. B. Grant. 1981. Selenium deficiency. Symptoms and control. N. Z. Min. Agric. and Fish., Aglink 3/4000/6/81:FPP 229.

Wilson, P. S. and G. J. Judson. 1976. "Glutathione peroxidase activity in bovine and ovine erythrocytes in relation to blood selenium concentration," Br. Vet. J. 132:428. 
